ELKOM, Vol.12, No.2, Desember 2019, pp. 1 - 9

p-ISSN : 1907-0012 (print)

e-ISSN : 2714-5417 (online)

http://ejurnal.stekom.ac.id/index.php/home

- page 1

\title{
Perancangan Media Pembelajaran Tata Surya Berbasis Multimedia dengan Metode Mind Mapping untuk Siswa Kelas IX SMP Muhammadiyah 3 Kaliwungu
}

\author{
Dimas Rahardian ${ }^{1}$, Toni Wijanarko Adi Putra ${ }^{2}$, Fitro Nur Hakim ${ }^{3}$ \\ ${ }^{1}$ Progdi Desain Grafis STEKOM Semarang \\ dimasrahar@gmail.com \\ ${ }^{2}$ Progdi Teknik Informatika STMIK Provisi Semarang \\ t.wijanarko@gmail.com \\ ${ }^{3}$ Progdi Teknik Informatika STMIK Provisi Semarang \\ masfitro@gmail.com² \\ Jl. Majapahit 605, Semarang, telp/fax : 024-6717201-02
}

\begin{tabular}{l}
\hline ARTICLE INFO \\
\hline Article history: \\
Received 30 November 2019 \\
Received in revised form 2 Desember 2019 \\
Accepted 10 Desember 2019 \\
Available online 12 Desember 2019
\end{tabular}

Available online 12 Desember 2019

\begin{abstract}
Based on the results of observation, the learning method used in SMP Muhammadiyah 3 Kaliwungu is in the form of discourse, discussions, question and answer with the book media. Learning methods that have been applied so far have not had enough impact on students' level of understanding. The method used is less successful, so students feel bored and bored. This study offers a solution for multimedia utilization with the Mind Map method as an interesting learning media, where computers can display text, images, videos and audio so that students can have a pleasant impression in the learning process. The validity value of media experts is 2.9 which is declared feasible, while the validity value of material experts is 3.3, which is declared feasible, and increases students' understanding and interest as users from $58.5 \%$ up to $80.5 \%$.
\end{abstract}

Keywords: multimedia, solar system, learning media, physics

\section{PENDAHULUAN}

Perkembangan kajian teknologi pendidikan menghasilkan berbagai konsep dan praktek pendidikan yang banyak memanfaatkan media sebagai sumber belajar. Dalam kaitannya dengan pembelajaran, teknologi pendidikan memperkuat dalam merekayasa berbagai cara dan teknik mulai dari tahap desain, pengembangan, pemanfaatan berbagai sumber belajar, implementasi, dan penilaian program serta hasil belajar [1].

SMP Muhammadiyah 3 Kaliwungu merupakan salah satu sekolah yang masih menerapkan Metode pembelajaran yaitu berupa buku pegangan dan metode ceramah saja.

Kegiatan belajar yang dilakukan SMP Muhammadiyah 3 Kaliwungu, peneliti mendapatkan ratarata mata pelajaran kelas IX pada tahun 2015-2016 dari hasil observasi dari 2 mata pelajaran yaitu IPA dan Bahasa Inggris. Didapatkan bahwa rata-rata IPA memiliki nilai terendah dibanding mata pelajaran Bahasa Inggris.

Received November 23, 2019; Revised November 29, 2019; Accepted Desember 12, 2019 
Tabel 1 Nilai Rata-Rata Tugas dan Ulangan Harian Mata Pelajaran Kelas IX Semester Genap

\begin{tabular}{|c|c|c|}
\hline Mata Pelajaran & IPA & Bhs. Inggris \\
\hline Rata-Rata & 60 & 65 \\
\hline
\end{tabular}

Data Tabel 1 di atas menunjukkan hasil rata-rata yang diperoleh dari dua mata pelajaran yaitu Bahasa Inggris dan Ilmu Pengetahuan Alam (IPA) belum sesuai Kriteria Ketuntasan Minimal (KKM) yang diterapkan SMP Muhammadiyah 3 Kaliwungu, yaitu 70.

Data lanjutan pada Tabel 2 yang diperoleh penulis setelah mendapatkan hasil rata-rata semua mata pelajaran kelas IX, berikutnya adalah nilai rata-rata materi mata pelajaran yang belum tuntas pada mata pelajaran IPA.

Tabel 2 Nilai Rata-Rata Tugas dan Ulangan Harian

Bahasa Inggris dan IPA Kelas IX Semester Genap

\begin{tabular}{|c|c|c|c|}
\hline Mata Pelajaran & Listrik & Magnet & Tata Surya \\
\hline Rata-Rata & 60 & 65 & 55 \\
\hline
\end{tabular}

Metode pembelajaran yang selama ini diterapkan belum cukup berdampak pada tingkat pemahaman siswa terhadap materi yang diajarkan sehingga penelitian ini bertujuan untuk mengembangkan media pembelajaran salah satunya dengan media pembelajaran berbasis multimedia.

Multimedia sangat dibutuhkan di sekolah karena multimedia membuat pembelajaran menjadi lebih lengkap dan lebih menarik serta dapat menjadi alat pengajaran elektronik yang dapat membantu pengajar [2].

Fisika adalah cabang ilmu IPA (Ilmu Pengetahuan Alam) yang merupakan ilmu eksperimental, fisikawan mengambil fenomena alam dan berusaha menemukan pola dan prinsip yang menghubungkan fenomena-fenomena ini.

Tata Surya merupakan materi dari mata pelajaran Fisika untuk pembelajaran wajib di SMP. Tata Surya adalah suatu kelompok benda langit, yaitu matahari dan planet-planet yang terdiri dari Merkurius, Venus, Bumi, Mars, Yupiter, Saturnus, Uranus, dan Neptunus satelit planet yang sudah diketahui sampai sekarang. Serta objek-objek tata surya lainnya seperti asteroid, planet katai, meteroid, planetoid, komet, dan debu antar planet yang bergerak mengikuti hukum-hukum dinamika Newton [3].

Mind Map adalah salah satu sistem pembelajaran yang paling dipakai di seluruh dunia. Sistem ini sudah membantu beratus-ratus juta orang di dunia untuk menggunakan kemampuan otaknya bertingkattingkat lebih tinggi dalam kegiatan berpikir dan belajar. Kontribusinya dalam membantu anak belajar secara lebih efektif, efisien, dan menyenangkan sudah terbukti dan mendapatkan pengakuan di seluruh dunia [4].

Mind Map adalah sistem yang "menyenangkan” kembali otak. Sistem ini mengadopsi banyak hal, termasuk asosiasi pikiran, gambar dan warna. Lebih dari itu, sistem ini juga menggunakan semua prinsip manajemen otak. Sistem ini benar-benar menunjukkan secara eksternal apa yang sebenarnya sedang terjadi dalam otak saat berpikir kreatif. Sistem ini juga akan menjamin pemberdayaan seluruh potensi dan kapasitas otak manusia karena sudah bekerja sesuai dengan kaidah-kaidah manajemen otak [5].

Prinsip kerja Mind Map adalah melibatkan kedua belah otak anak, juga bekerja sesuai dengan cara kerja alami otak anak, yaitu radiant thinking, atau pancaran pikiran yang berbeda pada setiap orang.

ELKOM Vol. 12, No. 2, Desember 2019: $1-9$ 
Metode ini juga mengoptimalkan aktivitas otak kiri dan otak kanan karena menggabungkan antara tulisan, urutan penulisan, hubungan antar kata, warna, gambar, dan bentuk [6].

Dengan adanya metode Mind Map, siswa akan terbantu untuk belajar, menyusun, dan menyimpan sebanyak mungkin informasi yang diinginkan dan mengelompokkannya dengan cara yang alami, memberi siswa akses yang mudah dan langsung kepada apapun yang diinginkan.

Sehingga penelitian ini bertujuan untuk merancang media pembelajaran Tata Surya berbasis multimedia terhadap pembelajaran pada siswa kelas IX SMP Muhammadiyah 3 Kaliwungu yang valid, serta menerapkan media pembelajaran Tata Surya dengan metode Mind Map yang efektif sebagai alat bantu guru.

\section{METODE PENGEMBANGAN}

Penelitian ini menggunakan metode penelitian dan pengembangan (Research and Development) adalah metode penelitian yang digunakan untuk menghasilkan produk tertentu, dan menguji keefektifan produk tersebut.

\section{A. Metode Penelitian}

Pada penelitian ini, permasalahan yang muncul di SMP Muhammadiyah 3 Kaliwungu yaitu nilai Fisika terutama materi Tata Surya dibawah KKM. Hal ini menimbulkan suatu pertanyaan bagaimana membuat media pembelajaran yang valid bagi SMP Muhammadiyah 3 Kaliwungu. Permasalahan yang muncul menghasilkan fakta bahwa metode ceramah, diskusi dan tanya jawab kurang berhasil digunakan sehingga nilai Tata Surya kurang maksimal dan dibutuhkan metode pelengkap lainnya.

Model pengembangan [8] tersebut mempunyai langkah-langkah sebagai berikut:

1. Penelitian dan pengumpulan data (Research and informing collecting)

2. Perencanaan penelitian (Planning)

3. Pengembangan produk awal (Develop preliminary form of Product)

4. Uji lapangan terbatas (Preliminary field testing)

5. Revisi hasil uji (Main product revision)

6. Uji lapangan lebih luas (Main field testing)

7. Revisi hasil uji lapangan luas (Operational product revision)

8. Uji kelayakan (Operational field testing)

9. Revisi hasil uji kelayakan (Final product revision)

10. Diseminasi dan sosialisasi produk akhir (Dissemination and Implementation)

Dimulai dengan Pengumpulan Data, desain produk, validasi desain, perbaikan desain untuk mengetahui desain media pembeljaran yang terbaik bagi siswa. Setelah itu implementasi tahap uji coba produk, dan analisa subjek uji coba.

\section{B. Validasi Desain}

Validasi desain merupakan salah satu proses pengembangan yang dilakukan guna mengetahui tingkat keefektifan produk tersebut. Uji validitas menghadirkan para ahli materi serta ahli media dengan penilaian menggunakan angket. Dalam Tabel 3 dan Tabel 4 dijelaskan bahwa penilaian menggunakan angket, terbagi atas 3 angket, yakni angket ditujukan bagi validator (para ahli desain), siswa (pengguna media), serta guru (para ahli materi).

Tabel 3. Angket Validasi Ahli Media

\begin{tabular}{|c|l|c|c|c|c|}
\hline No & \multicolumn{1}{|c|}{ Indikator } & $\mathbf{1}$ & $\mathbf{2}$ & $\mathbf{3}$ & $\mathbf{4}$ \\
\hline A & Kegiatan Input & & & & \\
\hline$\cdot$ & Aplikasi berjalan sebagaimana mestinya & & & $\sqrt{ }$ & \\
\hline 2. & Animasi berjalan sebagaimana mestinya & & $\sqrt{ }$ & & \\
\hline
\end{tabular}

Perancangan Media Pembelajaran Tata Surya Berbasis Multimedia dengan Metode Mind Mapping untuk Siswa Kelas IX SMP Muhammadiyah 3 Kaliwungu (Dimas Rahardian) 


\begin{tabular}{|c|c|c|c|c|}
\hline 3. & Kesesuaian penempatan tata letak (layout) & & $\sqrt{ }$ & \\
\hline 4. & Keterbacaan teks (font) & & $\sqrt{ }$ & \\
\hline 5. & Fungsi tombol berjalan dengan baik & & & $\sqrt{ }$ \\
\hline 6. & Kemudahan pengoperasian media pembelajaran & & $\sqrt{ }$ & \\
\hline 7. & Kesesuaian warna & & $\sqrt{ }$ & \\
\hline 8. & Kesesuaian suara (sound) & & $\sqrt{ }$ & \\
\hline 9. & Kesesuaian gambar icon untuk tombol & $\sqrt{ }$ & & \\
\hline \multirow[t]{3}{*}{10.} & $\begin{array}{l}\text { Komunikatif; sesuai dengan pesan dan dapat } \\
\text { diterima atau sejalan dengan keinginan sasaran }\end{array}$ & & $\sqrt{ }$ & \\
\hline & JUMLAH SKOR & 4 & 21 & 4 \\
\hline & JUMLAH SKOR TOTAL & \multicolumn{3}{|c|}{29} \\
\hline
\end{tabular}

Tabel 4. Angket Validasi Ahli Materi

\begin{tabular}{|c|c|c|c|c|c|}
\hline No & Indikator & & & & \\
\hline A. & Kegiatan Input & & & & \\
\hline 1. & Fasilitas media pembelajaran sudah terpenuhi & & & $\sqrt{ }$ & \\
\hline 2. & $\begin{array}{l}\text { Kegunaan media pembelajaran membantu proses } \\
\text { belajar }\end{array}$ & & & & $\sqrt{ }$ \\
\hline 3. & Kesesuaian penyampaian materi & & & $\sqrt{ }$ & \\
\hline 4. & $\begin{array}{l}\text { Media pembelajaran hadir dengan cara yang } \\
\text { menarik }\end{array}$ & & & & $\sqrt{ }$ \\
\hline 5. & Bahasa yang digunakan untuk siswa SMP & & & $\sqrt{ }$ & \\
\hline 6. & $\begin{array}{l}\text { Media pembelajaran memotivasi dalam mengikuti } \\
\text { materi Tata Surya }\end{array}$ & & & $\sqrt{ }$ & \\
\hline 7. & Fungsinya sebagai pendamping buku cetak & & & $\sqrt{ }$ & \\
\hline 8. & $\begin{array}{l}\text { Siswa mudah menjawab soal materi pelajaran dan } \\
\text { menghafal planet-planet pada materi Tata Surya }\end{array}$ & & & & $\sqrt{ }$ \\
\hline 9. & Fungsinya sebagai pembantu guru & & & $\sqrt{ }$ & \\
\hline 10. & Kesesuaian tingkat evaluasi dengan yang diajarkan & & & $\sqrt{ }$ & \\
\hline & JUMLAH SKOR & & & 21 & 12 \\
\hline & JUMLAH SKOR TOTAL & \multicolumn{4}{|c|}{33} \\
\hline
\end{tabular}

ELKOM Vol. 12, No. 2, Desember 2019: 1 -9 
Penilaian terbagi atas 4 skor, yaitu:

1. Skor 4: sangat baik, sangat layak, sangat menarik

2. Skor 3: baik, layak, menarik

3. Skor 2: kurang baik, kurang layak, kurang menarik

4. Skor 1: tidak baik, tidak layak, tidak menarik

Perhitungan validasi dapat diterapkan dengan rumus: $\mu=x$.

Keterangan:

$$
\begin{aligned}
& \mu=\text { nilai rata-rata } \\
& \mathrm{x}=\text { jumlah total nilai validasi } \\
& \mathrm{n}=\text { jumlah validator. }
\end{aligned}
$$

Dalam penelitian ini, respon siswa terhadap penggunaan media pembelajaran dilihat melalui angket dan nilai. Angket tersebut diberikan kepada siswa di akhir kegiatan proses pembelajaran. Siswa diminta menjawab sejujur-jujurnya atas pertanyaan yang berkaitan dengan pendapat siswa mengenai penggunaan media oleh guru. Adapun persentase skor per item dari masing-masing jawaban angket siswa dapat dilihat pada tabel.

\section{HASIL DAN PEMBAHASAN}

A. Hasil Pengembanganan

Pada hasil pengembangan, media yang dipilih sebagai pembelajaran tata surya berbasis multimedia untuk siswa kelas IX yakni menampilkan penjelasan materi-materi tata surya dengan desain maupun tampilan yang menarik dan apik, menyesuaikan dengan bagian dari konsep.

\section{B. Desain Visual Media}

Media pembelajaran ini dikembangkan dengan metode Mind Map dengan bantuan perangkat lunak: Macromedia Flash 8, Adobe Illustrator, Audacity, dan Adobe After Effect.

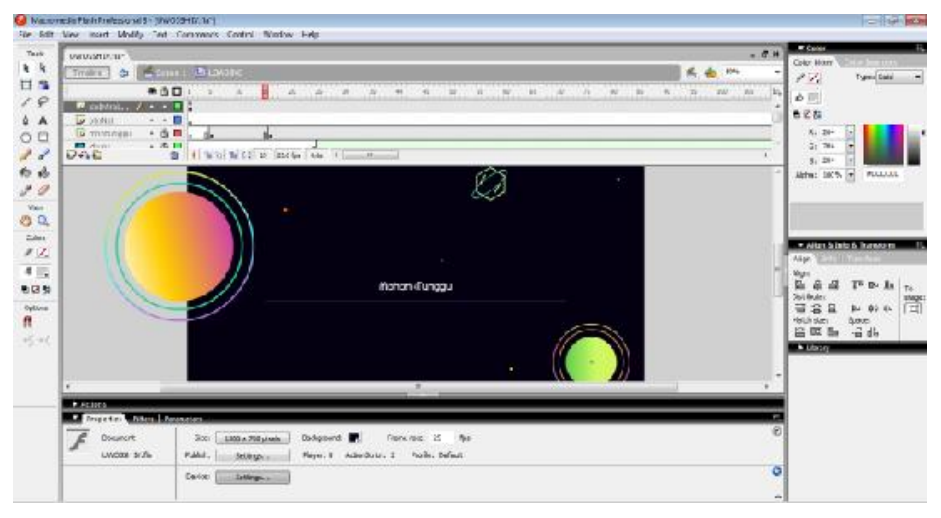

Gambar 1 Halaman Tunggu Pada Media Pembelajaran

Pada Gambar 1 memperlihatkan pola mengatur ukuran lembar kerja sesuai rancangan dan merubah fps-nya dari 12 ke 25. Melanjutkan tahap dengan memasukan gambar untuk pembukaan atau halaman tunggu media pembelajaran. Selanjutnya pada Gambar 2 dan Gambar 3 akan menjelaskan materi Tata Surya dan diakhiri dengan fitur evaluasi yang dapat dilihat pada Gambar 4. 


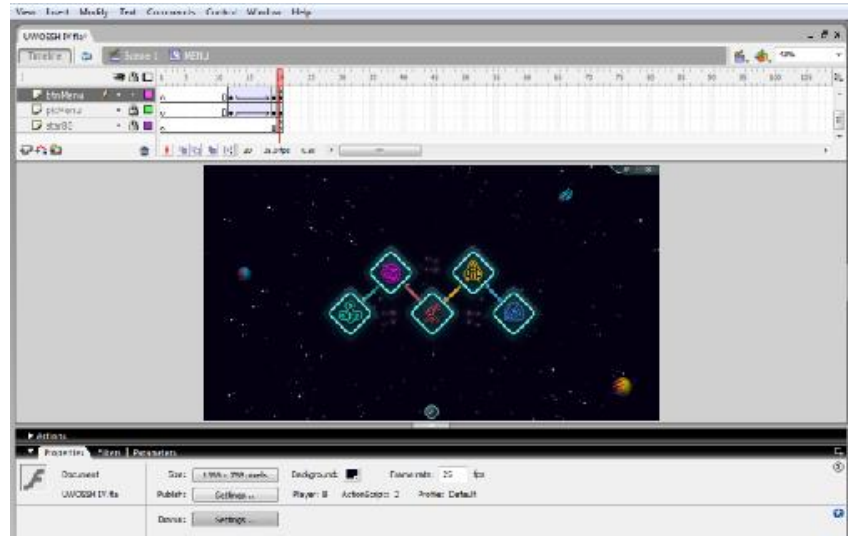

Gambar 2 Tampilan Home Page

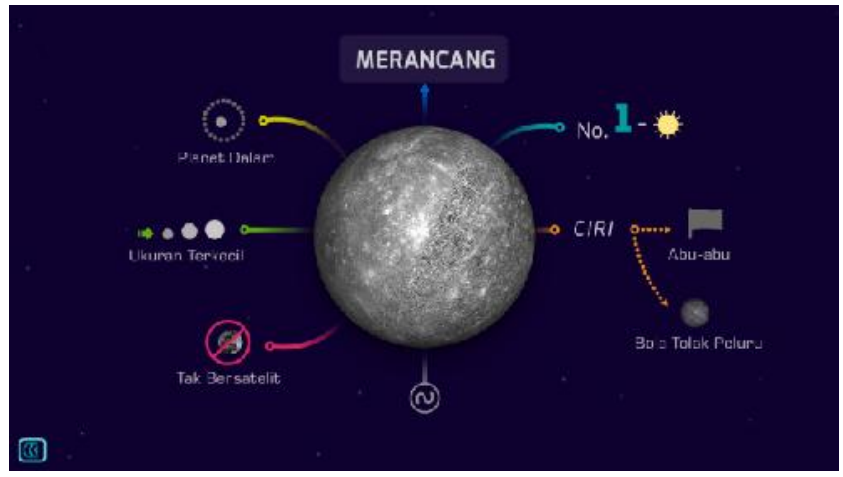

Gambar 3 Tampilan Materi Planet

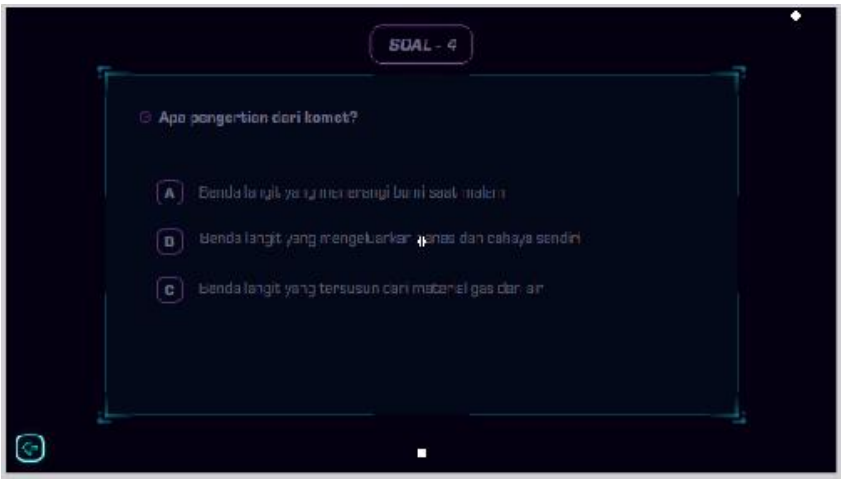

Gambar 4. Tampilan Halaman Evaluasi

\section{Pembahasan Produk Akhir}

Penentuan kelayakan perancangan media pembelajaran Tata Surya berbasis multimedia di SMP Muhammadiyah 3 Kaliwungu diukur berdasarkan penilaian (validasi) dari para ahli yaitu ahli media, ahli materi dan validasi dari user pada uji coba produk. Saran yang terdapat dalan instrument digunakan sebagai bahan pertimbangan untuk perbaikan alat bantu lebih lanjut. Berikut adalah hasil pengujian dari masingmasing validator.

\section{C.1. Validasi Ahli Media}

Pada Tabel 5 berikut adalah hasil validasi ahli media

ELKOM Vol. 12, No. 2, Desember 2019: 1 -9 
Tabel 5 Penilaian Validasi Ahli Media

\begin{tabular}{|c|c|}
\hline Nilai & Kriteria Kevalidasi \\
\hline $3,26-4,00$ & Sangat Valid \\
\hline $2,51-3,25$ & Valid \\
\hline $1,76-2,50$ & Kurang Valid (revisi) \\
\hline $1,00-1,75$ & Tidak Valid (revisi total) \\
\hline
\end{tabular}

Dari hasil pengujian melalui angket yang berjumlah 10 pertanyaan, nilai yang diperoleh:
a. Kurang
$(1 \times 0)=0$
b. Cukup
$(2 \times 2)=4$
c. Baik
$(3 \times 7)=21$
d. Sangat baik
$(\underline{4 \times 1)}=4+$

Sehingga dapat dihitung nilai validasinya: $\mu={ }_{n}^{\sum x}={ }_{10}^{29}=2,9$

Berdasarkan perhitungan di atas, diketahui bahwa hasil validasi dari ahli media adalah 2,9 kriteria ini berada diantara 2,51-3,25 yaitu tergolong dalam kategori valid, sehingga dapat dikatakan layak.

\section{C.2. Validasi Ahli Materi}

Dari hasil pengujian melalui angket yang berjumlah 10 pertanyaan, nilai yang di peroleh.
a. Kurang
$(1 \times 0)=0$
b. Cukup
$(2 \times 0)=0$
c. Baik
$(3 \times 7)=21$
d. Sangat baik
$(4 \times 3)=\frac{12+}{3} 3$

Sehingga dapat dihitung nilai validasinya

$$
\mu=\frac{\sum x}{n}=\frac{33}{10}=3,3
$$

Berdasarkan perhitungan diatas, diketahui bahwa hasil validasi dari ahli materi adalah 3,3. Kriteria ini berada diantara 3,26 - 4,00 yaitu tergolong dalam kategori sangat valid. Sehingga produk ini dapat dikatakan layak.

\section{C.3. Validasi User}

Kelompok kecil yang menilai merupakan siswa di SMP Muhammadiyah 3 Kaliwungu sebanyak 10 siswa. Inti yang diperoleh pada penelitian ini yakni data kuantitatif dan data kualitatif. Data kuantitatif merupakan data nilai yang diperoleh dari pembagian angket dimana untuk selanjutnya disusun dalam skala bertingkat. Data kualitatif merupakan data yang berupa kritik dan saran yang ditulis didalam angket sehingga data yang dihasilkan dapat sesuai dengan apa yang diharapkan pengguna.

\section{C.4. Hasil Uji Media}

Penelitian berdasarkan nilai dilakukan sebelum menggunakan media dan setelah menggunakan media. Dalam hal ini dapat dilihat pada Tabel 6, dan terdapat nilai sebelum menggunakan media. 
Tabel 6. Rata-Rata Nilai Siswa Sebelum Menggunakan Media

\begin{tabular}{|c|c|c|c|c|c|}
\hline \multirow{2}{*}{ Responden } & \multicolumn{4}{|c|}{ Nilai } & \multirow{2}{*}{ Jumlah } \\
\hline & 1 & 2 & 3 & 4 & \\
\hline 1. & 3 & 5 & 2 & 0 & 19 \\
\hline 2. & 3 & 7 & 0 & 0 & 17 \\
\hline 3. & 4 & 6 & 0 & 0 & 16 \\
\hline 4. & 5 & 5 & 0 & 0 & 15 \\
\hline 5. & 4 & 6 & 0 & 0 & 16 \\
\hline 6. & 5 & 4 & 1 & 0 & 16 \\
\hline 7. & 2 & 7 & 1 & 0 & 19 \\
\hline 8. & 4 & 5 & 1 & 0 & 17 \\
\hline 9. & 5 & 5 & 0 & 0 & 15 \\
\hline 10. & 6 & 4 & 0 & 0 & 14 \\
\hline \multicolumn{5}{|c|}{ Jumlah Total } & 164 \\
\hline
\end{tabular}

Data yang diperoleh sebelum menggunakan media adalah 1,64 setelah dihitung dengan rumus dan belum mencapai KKM yang ditetapkan di SMP Muhammadiyah 3 Kaliwungu. Berikutnya Tabel 7 adalah data nilai berdasarkan setelah menggunakan media.

Tabel 7. Rata-Rata Nilai Siswa Sesudah Menggunakan Media

\begin{tabular}{|c|c|c|c|c|c|}
\hline \multirow{2}{*}{ Responden } & \multicolumn{4}{|c|}{ Nilai } & \multirow{2}{*}{ Jumlah } \\
\hline & 1 & 2 & 3 & 4 & \\
\hline 1. & 0 & 0 & 8 & 2 & 32 \\
\hline 2. & 0 & 0 & 7 & 3 & 33 \\
\hline 3. & 0 & 0 & 6 & 4 & 34 \\
\hline 4. & 0 & 0 & 8 & 2 & 32 \\
\hline 5. & 0 & 1 & 7 & 2 & 31 \\
\hline 6. & 0 & 1 & 4 & 5 & 34 \\
\hline 7. & 0 & 0 & 9 & 1 & 31 \\
\hline 8. & 0 & 0 & 5 & 5 & 35 \\
\hline 9. & 0 & 0 & 8 & 2 & 32 \\
\hline 10. & 0 & 0 & 7 & 3 & 33 \\
\hline \multicolumn{5}{|c|}{ Jumlah Total } & 327 \\
\hline
\end{tabular}

Data yang diperoleh setelah menggunakan media adalah 3,27 setelah dihitung dengan rumus dan telah mencapai KKM yang ditetapkan di SMP Muhammadiyah 3 Kaliwungu.

\section{C.5. Nilai Rata-Rata Sebelum dan Setelah Menggunakan Media Pembelajaran}

Berdasarkan data nilai kelayakan yang menggunakan media pembelajaran berbasis multimedia dan yang tidak menggunakannya, telah diperoleh 1,64 yaitu pengguna yang menggunakan cara konvensional dan nilai 3,27 untuk yang memakai media pembelajaran berbasis multiedia, kemudian data nilai rata-rata evaluasi yang menggunakan media pembelajaran berbasis multiedia dan tidak menggunakannya, telah diperoleh yakni 58,5 untuk cara konvensional dan nilai 80,5 yang memakai media pembelajaran berbasis multiedia. Berikut ini adalah grafiknya:

ELKOM Vol. 12, No. 2, Desember 2019 : 1 -9 


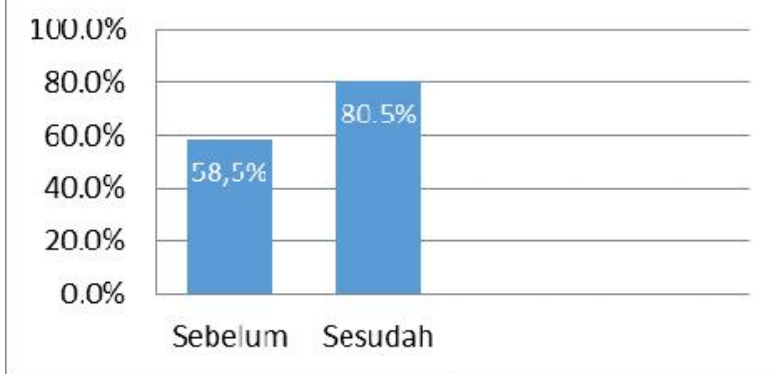

Gambar 5 Grafik Penilaian Pengguna

Berdasarkan grafik Gambar 5 diatas jika dibandingkan perolehan nilai 80,5\% untuk penggguna yang menggunakan media pembelajaran dan 58,5\% yang menggunakan cara konvensional, maka diperoleh kenaikan angka evaluasi pada media pembelajaran sebesar $22 \%$.

\section{KESIMPULAN}

Berdasarkan hasil penelitian, perancangan, dan pengujian terhadap media pembelajaran yang dilakukan di SMP Muhammadiyah 3 Kaliwungu dapat ditarik kesimpulan sebagai berikut:

1. Teknologi Informasi dan Komunikasi dalam model media pembelajaran telah berkembang dengan cepat. Termasuk menggunakan alat bantu perangkat komputer bahkan seluler. Perkembangan tersebut mengacu pada teknologi berbasis multimedia serta berbasis internet. Namun perolehan prestasi belajar di sekolah Indonesia masih pada tahap berkembang, belum berada pada tahap maju. Terlebih peneliti menemukan adanya permasalahan nilai yang kurang maksimal pada mata pelajaran fisika terutama materi tata surya di SMP Muhammadiyah 3 Kaliwungu.

2. Salah satu langkah yang tepat dalam memaksimalkan pembelajaran adalah menggunakan media pembelajaran berbasis multimedia disertai pemilihan metode pengajaran yang cocok, ketimbang hanya mengandalkan pembelajaran konvensional. Metode Mind Map merupakan alternatif dalam pembelajaran yang dapat membantu guru serta meningkatkan minat belajar siswa, dengan begitu media pembelajaran berbasis multimedia dan metode Mind Map menjadi pembuatan produk peneliti menggunakan software Macromedia Flash 8, Adobe Illustrator, Audacity, dan Adobe After Effect. Kemudian produk divalidasi oleh ahli media dengan nilai: 2,9 dan ahli materi dengan nilai: 3,3, maka produk dapat dikatakan layak atau valid.

3. Hasil yang didapat melalui media pembelajaran berbasis multimedia dan dipadukan dengan metode Mind Map adalah pengguna dapat memahami materi dengan lebih mudah, menyenangkan, juga menarik, sehingga minat belajar menjadi meningkat dan nilai dapat dimaksimalkan dengan baik. Hal tersebut terbukti dari nilai yang diperoleh siswa (user) sebelum menggunakan produk: 1,64 dan sesudah menggunakan produk: 3,27. Kemudian nilai rata-rata yang diperoleh siswa sebelum menggunakan produk: 58,5 dan untuk siswa yang telah menggunakan produk: 80,5 . Nilai tersebut menunjukkan kategori efektif atau layak digunakan.

\section{DAFTAR PUSTAKA}

[1] Tim Pengembang Ilmu Penndidikan FIP-UPI, 2007; “Ilmu dan Aplikasi Pendidikan, Pendidikan Disiplin Ilmu (bagian tiga)”, PT IMTIMA.

[2] Binanto, Iwan, 2010; “Multi Media Digital, Dasar Teori dan Pengembangannya”, Yogyakarta: CV. Andi Offset

[3] Admiranto, A.G., 2009; “Menjelajahi Tata Surya (edisi kedua)”, Yogyakarta: Kanisius.

[4] Windura, Susanto, 2008; “Mind Map, Langkah Demi Langkah”, Jakarta: PT Elex Media Komputindo.

[5] Windura, Susanto, 2009; “Mind Map, For Business Effectiveness”, Jakarta: PT Elex Media Komputindo.

[6] Jubilee Enterprise, 2010; “Berburu Ide Segar di Tengah Krisis dengan Internet”, Jakarta: PT Elex Media Komputindo.

Perancangan Media Pembelajaran Tata Surya Berbasis Multimedia dengan Metode Mind Mapping untuk Siswa Kelas IX SMP Muhammadiyah 3 Kaliwungu (Dimas Rahardian) 